\title{
Muhammad and the Believers at the Origins of Islam
}

\author{
Fred M. Donner
}

Cambridge, MA, Harvard University Press, 2010, hbk., 280 pages

Fred Donner's Muhammad and the Believer's at the Origins of Islam is the most recent in a long line of books that have attempted to recast the narrative of the early history of Islam in ways that seek to challenge both traditional Islamic readings of the sources and previous academic scholarship. Donner explicitly states that his book has two goals. The first is to challenge the notion that he sees as permeating Western scholarship on Islam: that the Prophet Muhammad (ȘAAS) and his followers were mainly motivated by factors other than religion - that is to say, that Islam was more of a political movement than a religious one. On this point, Donner argues persuasively that the primary motivation guiding the Prophet and his movement was religious and that his message was a clarion call to monotheism and piety 
that built upon Christianity and Judaism. More controversially, Donner argues that the Prophet Muhammad was less the founder of a new religious community than "an inspired visionary" who "inaugurated a pietistic religious movement that we can best call, followings its adherents own usage, the Believers movement (86-87)." This movement was not in its origins a new religion but instead an ecumenical community, which included not only Arabs newly converted to monotheism but also Christians and Jews. Donner's second task is to counter the notion that that the Umayyads were "cynical manipulators of the outward trappings of the religious movement begun by Muhammad (xii)." Instead, Donner seeks to rehabilitates the Umayyads "as rulers who sought practical ways to realize the most important goals of the movement and perhaps more than anyone else helped the Believers attain a clear sense of their own distinct identity and of their legitimacy as a religious community (xii)."

While this is a far less radical critique of the traditional readings of Islamic history than for example Crone and Cooke's Hagarism, it is still a dramatic revision of the way that Muslims have understood their own history that in the end it is both unsatisfying and unconvincing. As with all revisionist history, much of Donner's argument rests on the question of how much one can trust the early sources for reliable Islamic history. Donner makes the reasonable decision to treat the Qur'an as the most reliable source for understanding the history of the Prophet and early Islam. Based on this, he argues convincingly that religious motivations were at the heart of the early movement of what became Islam. However, Donner presents the religious worldview of the Qur'an as remarkably simplistic, exoteric, and pietistic in nature. Thus, the religion of the Believers' movement, as he describes it, strongly resembles the pietism of the Protestant Reformation. In fact, Donner goes so far as to identify the Kharijites as the movement that most accurately represents the "survival in its purest form of the original pietistic impulse of the Believers' movement of Muhammad (164)." While this is certainly one possible reading of the religious worldview of the Qur'an, it completely ignores those aspects of the Qur'an, which generations of Muslims have seen as sources of both mysticism and social ethics. If this was the only book one were to read about the early history of Islam, one would easily come away with the notion that the devotional piety, which lies at the heart of both Sufism and Shi' ism, is somehow alien to the essential worldview of the Qur'an.

While Donner's larger argument that the "Believers' movement” was originally ecumenical in nature has strong merit, his attempt to rehabili- 
tate the Umayyads - which takes up the majority of his book - is far less convincing. Despite his claim to emphasize the role of religion in the early period of Islam, Donner presents the struggle between the Umayyads and Ali and his supporters as primarily an internal political struggle within the Quraysh over the khilafat, downplaying the crucial religious dimensions of that struggle. Interestingly, Donner argues that his version of events follows closely those of Wilferd Madelung's much more compelling and substantive The Succession to Muhammad-a book whose conclusions and analysis he summarily rejects by dismissing Madelung as a "partisan in the conflict unequivocally supporting the claims of Ali (252)." Unfortunately, it can more easily be argued that Donner has become a partisan supporter of Mu'awiyah and the Umayyads. The book includes numerous snide attacks on Ali and the ahl al-bayt (members of Ali's household), especially his son Hasan, that seem less rooted in scholarly analysis than in personal opinion.

Donner presents Muhammad and the Believers as a popular book and, more importantly, as a potential undergraduate textbook suitable for introductory courses on Islamic history and Islam. This is obvious from the fact that the book contains no footnotes or other citations, instead including suggestions for further reading. As such, it is a book that deserves our attention as it seeks not only to present a new narrative, but to do so for college students many of whom will be approaching Islamic history for the first time. In the end, Donner's narrative of the early period of Islam lacks the complexity and nuance of earlier textbooks - especially Marshall G. S. Hodgson's The Venture of Islam, vol. 1, which to my mind still remains the best academic introduction to the issues surrounding the emergence of Islam as a religious movement. Surprisingly, Hodgson's work is largely ignored by Donner and is not mentioned in his suggestions for further reading. And that is a pity, for in my opinion, the success of The Venture of Islam, vol. 1 as an introduction to the early period of Islamic history is rooted in the fact that it does precisely what Donner claims to set out to do - take the religious dimensions of the early history of Islam seriously. Hodgson, however, does so in a way that incorporates the religious diversity inherent in Islam from its very origin, a diversity that Donner's book unfortunately ignores.

Vernon James Schubel NEH Distinguished Teaching Professor of Religious Studies Director, Islamic Civilization and Cultures Kenyon College schubel@kenyon.edu 